\title{
DRUŠTVENI MEDIJI U MARKETINŠKOJ KOMUNIKACIJI HRVATSKIH NAKLADNIKA
}

\author{
SOCIAL MEDIA MARKETING \\ IN CROATIAN BOOK PUBLISHING SECTOR
}

\author{
Dijana Oršolić Hrstić \\ dijana.orsolic@znanje.hr \\ Znanje. d.o.o., Zagreb
}

UDK / UDC 655.41: [004.087: 339.138]

Izvorni znanstveni rad / Original scientific paper

Primljeno / Received: 13. 12. 2018.

Prihvaćeno / Accepted: 17. 4. 2019.

\section{Sažetak}

Cilj. Cilj je rada davanje doprinosa problematici oglašavanja kroz društvene medije unutar hrvatskog nakladničkog sektora te utvrđivanje značaja društvenih medija i elektroničke preporuke u marketinškim strategijama nakladničkog sektora i komunikaciji prema čitatelju.

Pristup. Prvi dio rada usmjeren je na pretraživanje sekundarnih izvora podataka (znanstvena i stručna literatura te postojeće baze podataka), koji su poslužili za izradu teorijskog dijela rada i anketnog upitnika. Primarno istraživanje provedeno je metodom strukturiranog anketnog upitnika putem elektroničke pošte na prosudbenom uzorku komercijalnih nakladnika u Hrvatskoj.

Rezultati istraživanja. Trend digitalizacije marketinške komunikacije te porasta važnosti i utjecaja društvenih medija preslikava se i na tržište knjige u Hrvatskoj, na kojem se također može primijetiti značajnija orijentacija prema digitalnom marketingu, oglašavanju na društvenim mrežama i izgradnji partnerskog PR-odnosa s vođama mišljenja, a samim time i korištenju elektroničke preporuke.

Originalnost. Temeljni doprinos rada ogleda se u definiranju važnosti utjecaja društvenih medija i elektroničke preporuke u suvremenoj komunikaciji nakladnika s čitate-

Vjesnik bibliotekara Hrvatske 62, 1(2019), 189-217

ISSN 0507-1925

(C) VBH 2018. 
ljem, s ciljem poticanja nakladnika na aktivno usmjeravanje ove vrste komunikacije u svrhu širenja kulture čitanja knjige.

Ograničenja. Istraživanje je provedeno na prosudbenom namjernom uzorku, zbog čega je nemoguće na osnovi dobivenih rezultata izvoditi zaključke o cjelokupnom tržištu knjige u Hrvatskoj.

Ključne riječi: društveni mediji, elektronička preporuka, knjiga, nakladništvo.

\begin{abstract}
Purpose. The aim of the paper is to contribute to the issue of social media advertising in the Croatian publishing sector and to identify the importance of social media and electronic word of mouth in the marketing communication of publishers and readers.
\end{abstract}

Approach. The first part of the paper focuses on secondary research (scientific and professional literature, and existing databases). Primary research was conducted on a convenience sample of Croatian publishers by questionnaire via e-mail.

Results. The trend of digitization of marketing communications, as well as an increase in the importance and impact of social media, is also present in the Croatian publishing sector. Significant orientation towards digital marketing, social media, publicity and electronic word of mouth is noticeable.

Originality. The fundamental contribution of the paper is reflected in the definition of the importance of social media influence and electronic word of mouth in marketing communication of the publishing sector, with the aim of encouraging the publishers to actively direct this kind of communication for the purpose of expanding the reading culture.

Limitations. The research was conducted on a convenient sample, so it is not possible to draw conclusions on the entire publishing market in Croatia based on the results obtained.

Keywords: book, publishing, electronic word of mouth, social media

\title{
1. Uvod
}

U vremenu kada se slika medijskog svijeta mijenja na dnevnoj razini, marketing dobiva sve veći značaj u okviru poslovnih procesa unutar poduzeća te se u marketinške kampanje ulaže sve više sredstava i energije kako bi se ostvarili pojedini poslovni ciljevi i kako bi ciljna poruka došla do krajnjeg korisnika. Načini i strategije marketinške komunikacije kontinuirano se kroz vrijeme mijenjaju i prilagođavaju kako bi efikasno pratile potrošača i ostvarile odnos s njim. Uočljiv je sve veći stupanj prisutnosti društvenih medija te, umjesto dosadašnjih masovnih, 
dolazi novo razdoblje osobnih i participirajućih medija. Posebno se ističe stalni porast udjela elektroničkog oglašavanja u marketinškoj komunikaciji. Gotovo je nezamislivo da renomirano poduzeće nema vlastite mrežne stranice, internetsku trgovinu i aktivan poslovni profil na bar jednoj od društvenih mreža. Dok su se u analognom svijetu oglašavanja stvari događale statično, u digitalnom okruženju marketinška komunikacija postaje kompleksnija, raznovrsnija i kreativnija, a uloga krajnjeg potrošača iz pasivne postaje aktivna kroz sve prisutniji fenomen elektroničke preporuke.

Taj trend nije zaobišao ni tržište knjige, koje se u pravilu kroz povijest uvijek više oslanjalo na publicitet kroz odnose $s$ javnošću nego na plaćeno oglašavanje zakupom medijskog prostora, što je dobilo još veći zamah stupanjem društvenih medija na scenu. Oni nude mogućnost direktne dvosmjerne komunikacije s krajnjim potrošačem u bilo kojem trenutku bez obzira na to gdje se potrošač nalazi, podržavaju novi mrežni model usmene predaje - elektroničku preporuku - i stvaraju novi val vođa mišljenja ${ }^{1}$ koji putem vlastitih blogova i stranica na društvenim mrežama potiču širu javnost na čitanje te u dogovoru s nakladnicima recenziraju pojedine naslove i djeluju kao njihovi predstavnici. Društveni mediji omogućavaju nakladnicima i vođenje vlastitih poslovnih stranica putem kojih mogu bez većih troškova plasirati informacije o novim naslovima i akcijama te poticati konverzaciju o naslovima među svojim čitateljima koji su sudionici društvenih mreža i na taj način poticati još jedan vid elektroničke preporuke.

\section{Metodologija istraživanja i cilj rada}

Cilj je ovog rada bio utvrditi u kojoj mjeri hrvatski komercijalni nakladnici (kojima je nakladništvo primarna djelatnost) koji se bave tradicionalnim knjižnim nakladništvom (knjigom u tiskanom obliku) koriste društvene medije kao dio vlastite marketinške komunikacije, i to trojako: (1) posjedovanjem aktivnog poslovnog profila na društvenim mrežama, (2) korištenjem plaćenih oglasa na internetu i na društvenim medijima te (3) suradnjom s nekomercijalnim društvenim medijima koji prate kretanja na nakladničkom tržištu u Hrvatskoj kroz publicitet koji je definiran kao „besplatna promocijska aktivnost koja djeluje na poboljšanje imidža, djeluje kao novost i utječe na veliki broj ljudi““. ${ }^{2} \mathrm{U}$ ovom slučaju kao jedan od tipova publiciteta na društvenim medijima istraživan je pojam elektroničke preporuke (pod pojmom elektroničke preporuke u ovom istraživanju podrazumijevaju se komentari čitatelja na mrežnim stranicama izdavača i stranicama izdavača na društvenim medijima te komentari, osvrti i recenzije čitatelja na nekomercijalnim

1 Engl. influencer, utjecajni pojedinac koji kreira stav javnosti o određenim temama.

2 Kesić, T. Integrirana marketinška komunikacija: oglašavanje, unapređenje prodaje, Internet, odnosi s javnošću, publicitet, osobna prodaja. Zagreb: Opinio, 2003. Str. 18. 
društvenim medijima koji prate kretanja na nakladničkom tržištu u Hrvatskoj blogovima i stranicama na društvenim mrežama osnovanima od strane čitatelja).

Svrha je istraživanja davanje doprinosa problematici oglašavanja kroz društvene medije unutar hrvatskog nakladničkog sektora, a glavni cilj istraživanja jest utvrđivanje značaja društvenih medija i elektroničke preporuke u marketinškim strategijama nakladničkog sektora te u komunikaciji prema krajnjem korisniku, odnosno čitatelju. S obzirom na srodnost istraživanja, radovi autora L. Blaževića ${ }^{3}$, D. Živković ${ }^{4}$ i M. Radalja ${ }^{5}$ poslužili su kao polazište kod oblikovanja metodologije istraživanja i sastavljanja anketnog upitnika.

Kako bi se odredio uzorak, korištene su baze nakladnika Zajednice nakladnika i knjižara - ZNK i udruge nakladnika ZANA - te su nakladnici rangirani u skupine velikih, srednjih ili malih prema broju objavljenih novih naslova u 2015., 2016. i 2017. godini na temelju broja prijavljenih naslova u pojedinoj godini na stranicama Nacionalne i sveučilišne knjižnice $u$ Zagrebu. ${ }^{6}$ Usporedbom spomenutih baza dobiven je sveukupni broj od 131 nakladnika, i to 65 malih nakladnika (do 15 objavljenih naslova godišnje), 17 srednjih nakladnika (15-30 objavljenih naslova godišnje) i 20 velikih nakladnika (preko 30 objavljenih naslova godišnje).

Primarno istraživanje provedeno je metodom strukturiranog anketnog upitnika putem elektroničke pošte na namjernom uzorku komercijalnih nakladnika u Hrvatskoj. Na osnovi postavljenih parametara anketni upitnik poslan je u travnju 2018. godine na adrese sveukupno 51 nakladnika, i to po 17 nakladnika iz svake kategorije. U uvodnom dijelu upitnika istaknuta je napomena da ga treba popuniti voditelj marketinga ili voditelj prodaje, odnosno redakcije ako sektor marketinga ne postoji. Prikupljena su 33 potpuna odgovora - 11 iz kategorije velikih, 9 iz kategorije srednjih i 13 iz kategorije malih. Kako bi se poštovala struktura nakladnika dobivena na temelju broja objavljenih naslova u protekle tri godine (64\% malih nakladnika, $17 \%$ srednjih nakladnika i $19 \%$ velikih nakladnika), u analizu je uključeno ukupno 20 prikupljenih upitnika, i to 13 malih nakladnika, 3 srednja i 4 velika.

3 Blažević, L. Moć marketinga u knjižnom nakladništvu, Zagreb: Naklada Ljevak, 2016.

4 Živković, D. Elektronička knjiga. Zagreb: Multigraf, 2001.

5 Radalj, M. Knjiga i nakladništvo u odnosima s javnošću. Zagreb: Hrvatska sveučilišna naklada, 2016.

6 U kategoriju velikih nakladnika svrstani su svi nakladnici koji su u najmanje dvije od tri promatrane godine imali najmanje 30 objavljenih naslova te nakladnici koji su u jednoj godini imali preko 30 objavljenih naslova ako je trogodišnji prosjek iznosio više od 30 objavljenih naslova u godini. U kategoriju srednjih nakladnika svrstani su nakladnici koji su u najmanje dvije promatrane godine imali između 15 i 29 objavljenih naslova te nakladnici koji su u jednoj godini imali između 15 i 29 objavljenih naslova ako je trogodišnji prosjek iznosio najmanje 15 naslova u pojedinoj godini. U kategoriju malih nakladnika svrstani su nakladnici koji su unutar tri promatrane godine imali najmanje jedan objavljen naslov, ali ne više od 14 naslova u godini. 


\section{Društveni mediji i elektronička preporuka}

Digitalna tehnologija ključ je golemih tehnoloških promjena današnjice - komunikacija i društvena interakcija prelaze u digitalnu sferu i postaju imperativ i u poslovnom okruženju, a društveni mediji postaju neizostavan dio modernog društva. Tradicionalni mediji sve više gube na značaju u korist interneta, a internet i društveni mediji postaju središnje mjesto konzumacije zabave, vijesti te poslovne i društvene komunikacije. ${ }^{7}$ A. M. Kaplan i M. Haenlein definiraju društvene medije kao web-stranice ili internetske aplikacije izgrađene na tehnologiji web 2.0 u svrhu stvaranja i razmjene sadržaja od strane krajnjih korisnika, a obuhvaćaju niz komunikacijskih kanala putem kojih se stvara interakcija između pojedinaca $\mathrm{i}$ grupe, koji su nastali kao posljedica razvoja participativne kulture. ${ }^{8}$ A. M. Kaplan i M. Haenlein nude detaljnu podjelu društvenih medija na:

- kolaboracijske projekte - Wikipedija

- blogove i mikroblogove - Tumblr, Twitter

- društva sadržaja / content network - Youtube

- stranice za društveno umrežavanje - Facebook, Google Plus

- virtualne svjetove - World Of Warcraft, Second Life. ${ }^{9}$

Prema prvoj K. O'Reillyjevoj definiciji weba 2.0 korisnici su proizvođači, a ne samo potrošači sadržaja, usmjerenost je na korisnika, kolektivna inteligencija tumači se frazom „mi znači više nego ja“, a mreža služi kao platforma gdje je sve otvoreno i podijeljeno. ${ }^{10}$ Internet i lako dostupni društveni mediji stoga mijenjaju način na koji pojedinci i poduzeća komuniciraju, usmjeravanjem na korisnika i omogućavanjem razvoja participativne kulture u kojoj se nekadašnja pasivna publika uključuje, razmjenjuje mišljenja i postaje aktivni sukreator sadržaja.

Društveni mediji postaju značajan komunikacijski alat u brojnim djelatnostima, a ako je sadržaj poruke pogođen i ako je poruka plasirana na prikladnom društvenom mediju u pravom trenutku, doseg publike nerijetko može premašiti doseg plaćenog oglasa na tradicionalnom mediju.$^{11} \mathrm{M}$. Ferenčić smatra da je investiranje u oglašavanje kroz društvene medije postalo obavezan dio u raspodjeli komunikacijskih budžeta, a oni su postali nezaobilazan dio medijske strategije

\footnotetext{
7 Stanojević, M. Marketing na društvenim mrežama. // Medianali 5, 10(2011), str. 177.

8 Usp. Kaplan, A. M.; M. Haenlein. Users of the world, unite! The challenges and opportunities of social media. // Business horizons 53, 1(2010), str. 60. DOI: https://doi.org/10.1016/j. bushor.2009.09.003.

9 Isto, str. 62.

10 O’Reilly, K.; A. MacMillan; A. G. Mumuni; K. M. Lancendorfer. Extending our understanding of eWom impact: the role of source credibility and message relevance. // Journal of Internet Commerce 15, 2(2016), 77-96. DOI: http://dx.doi.org/10.1080/15332861.2016.1143215.

11 Jelić, N. Društveni mediji kao alat destinacijskog marketinga i njihova primjena od srane hrvatskih turističkih organizacija: diplomski rad. Zagreb: Ekonomski fakultet, 2015. Str. 15.
} 
kako malih tvrtki tako i velikih multinacionalnih kompanija. ${ }^{12}$ Prema P. Kotleru i K. L. Kelleru društveni mediji istovremeno utječu na masovnu i osobnu marketinšku komunikaciju, no autori ipak naglašavaju da je njihov utjecaj na osobnu komunikaciju snažniji. ${ }^{13}$ P. Ljevak navodi kako društveni mediji podrazumijevaju pristup tijekom 24 sata dnevno kroz sve dane u tjednu, interaktivni su i povoljni i čine glavne kanale osobne marketinške komunikacije, uzimajući u obzir karakteristike modernog umreženog društva. ${ }^{14} \mathrm{O}$ uzletu utjecaja društvenih medija govori i istraživanje The Nielsen Company provedeno 2009. godine koje donosi sljedeće zaključke:

- sudjelovanje populacije iznad 35 godina starosti u društvenim medijima raste

- društveni mediji najbrže su rastući segment interneta te popularniji servis od e-pošte

- oko $75 \%$ korisnika interneta prisutno je na društvenim medijima, koji čine više od $10 \%$ ukupnog prometa na internetu. ${ }^{15}$

Karakteristike društvenih medija iz perspektive marketinga prema J. H. Kietzmannu razlikuju se od tradicionalnog oglašavanja u kategorijama dosega, dostupnosti, upotrebljivosti, neposrednosti i stalnosti. ${ }^{16}$ Mogućnosti koje danas pružaju digitalna tehnologija i društveni mediji olakšavaju potrošačima jačanje i širenje njihovih krugova poznanstva i koriste se za razmjenu ideja, preporuke i savjete među širokom mrežom korisnika interneta. ${ }^{17}$ Društveni mediji koriste se za izgrađivanje društvenog autoriteta, pojedinci se postavljaju kao eksperti u svojim područjima te počinju na ta područja utjecati. Jedan od osnovnih koncepata društvenih medija jest taj da pomoću njih jedna osoba može doprinijeti razgovoru o nekoj pojavi, proizvodu, osobi i sl. te sudjelovati u kreiranju javnog mišljenja o njoj. ${ }^{18}$ Mučalo i Šop definiraju modernu korisničku publiku kao onu koja bez suzdržava-

12 Usp. Ferenčić, M. Marketinška komunikacija u digitalnom svijetu. // Praktični menadžment 3, 5(2012), 42-46.

13 Usp. Kotler, P.; K. L. Keller. Marketing management. 15th Kindle ed. Harlow: Pearson Education Limited, 2016. Str. 124.

14 Ljevak, P. Poslovne strategije nakladnika i korisnici digitalnih društvenih mreža: doktorska disertacija. Zadar: Odsjek za informacijske znanosti Sveučilišta, 2017. Str. 69. [citirano: 2018-0520]. Dostupno na: https://repozitorij.unizd.hr/islandora/object/unizd:1080/preview.

15 Jelić, N., Nav. dj., str 21.

16 Usp. Kietzmann, J.H.; K. Hermkens; I. P. McCarthy; B. S. Sillvestre. Social media? Get serious! Understanding the functional building blocks of social media. // Business Horizons 54, 1(2011), 241-251. DOI: https://doi.org/10.1016/j.bushor.2011.01.005.

17 Meuter, M.; D. Brown McCabe; J. Curran. Electronic word-of-mouth versus interpersonal word-of-mouth: are all forms of word-of-mouth equally influential? // Services Marketing Quarterly 34, 3(2013), str. 242. DOI: https://doi.org/10.1080/15332969.2013.798201.

18 Adams, D. The history of social media. // Instant Shift (2011). [citirano: 2017-03-16]. Dostupno na: http://www.instantshift.com/2011/10/20/the-history-of-social-media/. 
nja bira, sudjeluje, kreira, objavljuje, komunicira, razmjenjuje, kritizira, savjetuje, kupuje, mobilna je i nemilosrdna, aktivna i izbirljiva, informatički pismena i zahtjevna. ${ }^{19} \mathrm{U}$ tom kontekstu razvio se pojam elektroničke preporuke (engl. electronic-word-of-mouth ili word-of mouse) kao produžetak klasične usmene predaje, a definiran je kao javna izmjena mišljenja putem elektroničkog medija među ljudima koji se u pravilu nikada nisu upoznali i ni na koji način nisu društveno povezani. ${ }^{20}$ Komunikacija elektroničkom preporukom odnosi se na bilo koju pozitivnu ili negativnu izjavu potencijalnih, aktualnih ili bivših potrošača o proizvodu ili poduzeću koja je dostupna mnoštvu ljudi i institucija preko interneta. ${ }^{21}$ Može biti izražena u različitim oblicima kao što su mišljenje, ocjene i povratne informacije, recenzije, komentari i iskustvo podijeljeni na platformama za elektroničku komunikaciju poput blogova, preglednih web-stranica, foruma za raspravu, internetskih trgovina, mrežnih stranica poduzeća i društvenih mreža. ${ }^{22}$ „Budućnost je marketinga u usmenoj predaji (engl. word of mouth) o kvaliteti nekog proizvoda. ${ }^{\text {“23 }} \mathrm{Ri}$ ječi marketinškog stručnjaka P. Kotlera ukazuju na to kako u raznovrsnom svijetu marketinške komunikacije usmena predaja i preporuka od strane drugih potrošača uvijek ostaje nadmoćna nad svim ostalim vrstama promocije i masovnog oglašavanja. Uzimajući spomenuto u obzir, marketinški stručnjaci mogu kontrolirano poticati konverzaciju o vlastitim proizvodima među korisnicima društvenih medija. Preko $90 \%$ korisnika interneta čita recenzije i preporuke drugih korisnika, a $89 \%$ tvrdi da one utječu na njihovu odluku o kupnji, što podupire činjenicu da izgradnja pozitivne slike brenda na društvenim medijima zahtijeva visok stupanj povjerenja od strane potrošača. ${ }^{24} \mathrm{C}$. Birkner navodi da $55 \%$ potrošača odluku o kupnji donosi na osnovi preporuke s bloga, a $40 \%$ na osnovi preporuke s Facebooka. ${ }^{25} \mathrm{Tu}$ je nastao i pojam vođe mišljenja (engl. influencer) koji podrazumijeva identifikaciju pojedinaca koji imaju utjecaj na potencijalne kupce te orijentaciju marketinških aktivnosti oko takvih pojedinca koji se nazivaju vođama mišljenja, umjesto orijentacije na ciljno tržište u cjelini. M. Radalj za kreatore javnog mišljenja kaže da su ,utjecajni pojedinci koji kreiraju stav javnosti o određenim temama,

19 Mučalo M.; S. Šop. Nova publika novih medija. // Informatologija 41, 1(2008), str. 52, 55.

20 O'Reilly, K.; A. MacMillan; A. G. Mumuni; K. M. Lancendorfer. Nav. dj., str. 96.

21 Hennig-Thurau, T.; K. P. Gwinner; G. Walsh: D. D. Gremler. Electronic word-of-mouth via consumer-opinion platforms: what motivates consumers to articulate on the Internet. // Journal of Interactive Marketing 18, 1(2004), 38-42. DOI: https://doi.org/10.1002/dir.10073.

${ }^{22}$ Anubhav Mishra, S. M.S. eWOM: extant research review and future research avenues.//The Journal for Decision Makers 41, 3(2016), 222-233. DOI: https://doi.org/10.1177/0256090916650952.

${ }^{23}$ Kotler, P. Usmeno priopćenje (11. 10. 2006.) Citirano prema Haramija, P. Marketing usmenom predajom: fenomen i mogućnosti. // Bogoslovska smotra 77, 4(2007.), str. 881.

24 Barreda, A.; A. Bilgihan; Y. Kageyama. The role of trust in creating positive word of mouth and behavioral intentions: the case of online social networks. // Journal of Relationship Marketing 14, 1(2015), str. 30-31. DOI: https://doi.org/10.1080/15332667.2015.1006002.

25 Birkner, C. Mom's the word. // Marketing News 45, 6(2011), str. 8. [citirano: 2017-03-12]. Dostupno na: http://connection.ebscohost.com/c/articles/60497347/moms-word. 
osobe u određenim područjima koje drugi ljudi slušaju i prate “ ${ }^{26}$ Oni formiraju mreže tako što razgovaraju s drugim ljudima i pojedincima koji dijele informacije i gledišta o pojedinim temama i bolje su informirani od prosječne osobe. ${ }^{27}$ Sudeći prema navedenim trendovima, marketing na društvenim medijima predstavlja strategiju poduzeća usmjerenu na poticanje postojećih krajnjih potrošača i potencijalnih novih klijenata na direktnu međusobnu komunikaciju i razmjenu informacija o njihovu brendu, proizvodima ili uslugama. U smislu raširenosti platforme i snage u prenošenju elektroničke preporuke, K. Moniz navodi blog i društvene mrě̌e kao najpopularnije društvene medije. ${ }^{28}$

\subsection{Knjiga, nakladništvo i društveni mediji}

D. Živković u knjizi „Elektronička knjiga“ navodi kako dvojaka funkcija knjige kao kulturnog i gospodarskog dobra zahtijeva složen pristup knjizi. ${ }^{29}$ Dvojaku ulogu nakladništva ističe i J. B. Thompson, koji ga definira kao proces stvaranja i distribucije znanja i kulturnih vrijednosti, ali je istovremeno i komercijalna gospodarska djelatnost čiji je krajnji cilj profit. ${ }^{30} \mathrm{~S}$ obzirom na medij, razlikuju se tradicionalno i elektroničko nakladništvo. Tradicionalno nakladništvo podrazumijeva proizvodnju i distribuciju tiskanih knjiga i srodnih publikacija u materijalnom obliku (brošure, serijske publikacije, zemljovidi i muzikalije), a elektroničko nakladništvo koje se razvija 1990-ih podrazumijeva proizvodnju i distribuciju knjige u elektroničkom obliku (može biti na materijalnom mediju poput CD ROM-a, USB-a i sl. ili mrežno izdanje dostupno putem interneta). ${ }^{31}$ Tranzicija nakladništva u tržišno orijentiranu industriju naglašava potrebu primjene dobro integrirane marketinške komunikacije u poslovanje nakladničkih kuća s ciljem opstanka među sve većom konkurencijom na nesigurnom tržištu. Želi li biti uspješan, nakladnik mora imati sposobnost motivirati i potaknuti čitatelja na čitanje, odnosno kupnju naslova koje je objavio u vlastitoj nakladi, što je moguće ostvariti dobrim marketingom i kvalitetnom marketinškom strategijom. ${ }^{32}$

S obzirom na istovremeni gospodarski i kulturni izražaj, u suvremenom poslovanju nakladničkog sektora elektronički marketing zauzima važnu ulogu. $\mathrm{N}$.

\footnotetext{
26 Radalj, M. Nav. dj., str. 58-60.

27 Isto.

28 Usp. Moniz, K. Social media overview. // Tufts University (2014). [citirano: 2017-03-17]

Dostupno na: http://communications.tufts.edu/marketing-and-branding/social-media-overview/.

29 Živković, D. Nav. dj., str. 15.

30 Usp. Thompson, J. B. Books in digital age. Cambridge: Polity Press, 2005. Str 15-30.

31 Nakladništvo. // Hrvatska enciklopedija. Mrežno izd. Zagreb: Leksikografski zavod Miroslav Krleža, 2018. [citirano: 2019-01-15]. Dostupno na: http://www.enciklopedija.hr/natuknica. aspx?id=42840.
}

32 Usp. Blažević, L. Nav. dj., str. 35. 
Tomašević smatra da je funkcioniranje kreativne ekonomije u sve većoj mjeri pod utjecajem ubrzanog širenja i rastuće važnosti društvenih medija. ${ }^{33}$ Upravljanje marketingom postaje sve važnija odrednica koja čini razliku između uspješnih i neuspješnih nakladnika, a osobno komuniciranje putem društvenih medija u smislu isplativosti i dosega nakladničkom poslovanju otvara mnoge mogućnosti. ${ }^{34}$ Kao i u drugim industrijama, cilj je osigurati stabilno i profitabilno poslovanje, što podrazumijeva upravljanje marketingom i kombinaciju tradicionalnih i suvremenih elemenata marketinga. ${ }^{35} \mathrm{U}$ kontekstu marketinga podrazumijeva se primjena različitih tradicionalnih i suvremenih elemenata promocijskog miksa, ovisno o samom cilju promocije.

- Oglašavanje - u svrhu informiranja čitatelja o knjizi i usmjeravanja na kupnju knjige, a podrazumijeva svaki plaćeni oblik neosobne komunikacije u tradicionalnim medijima (u tisku, na televiziji ili radiju, na vanjskim površinama poput plakata na vidljivim mjestima i sl.) ili na digitalnim medijima (internet).

- Unapređivanje prodaje - u svrhu poticanja prodaje kroz promocije (popuste, uzorke, nagrade), potpisivanje knjiga, posebno pozicioniranje u knjižarama ili na drugom prodajnom mjestu, prodajne sajmove i sl.

- Odnosi s javnošću - privlačenje čitatelja, širenje informacija o knjigama i izgradnja ugleda putem publiciteta kroz publikacije, sponzorstva, konferencije i sl. (nakladnici sve više pažnje pridaju tom tipu promocije zbog manjeg troška i većeg utjecaja u odnosu na plaćeno oglašavanje).

- Direktni marketing - direktna komunikacija personaliziranim porukama već poznatim kupcima (loyalty-programi, baze podataka nakladnika).

- Osobna prodaja - trgovački putnici i osoban pristup kupcu (prodaja knjižarama, školama i sl.).

- Promocija putem interneta - mrežne stranice nakladnika, mrežne knjižare, stranice na društvenim medijima. ${ }^{36}$

U tom tonu nadovezuje se i zaključak autora koji uz primjenu novih tehnologija, koje snažno utječu na oblikovanje suvremenog marketinga, ističu važnost primjene tradicionalnih varijabli marketinga u suvremenom okruženju, odnosno fokusa na razvijanju odnosa i suradnji s klijentima i drugim sudionicima na tržištu. ${ }^{37}$ Sve više poduzeća okreće se novim individualiziranim komunikacijskim aktivnostima, što je posljedica digitalizacije koja kupcima omogućava bolji i trenutan pristup informacijama te u skladu s tim većina nakladnika danas ima vlastite mrežne

\footnotetext{
33 Tomašević, N. Kreativna industrija i nakladništvo. Zagreb: Naklada Ljevak, 2016. Str. 67.

34 Ljevak, P. Nav. dj., str. 69.

35 Usp. Blažević, L. Nav. dj. str. 52.

36 Isto, str. 52-59.

37 Isto, str.13.
} 
stranice $(97 \%)$ koje koriste za pospješivanje vidljivosti proizvodnog asortimana i kao dobar marketinški alat. Mrežna prisutnost nakladnika može biti koncipirana u vidu mrežne knjižare, stranica gdje se kupci informiraju i naručuju knjige (poticaj prodaje u tradicionalnim kanalima) te stranica koje potiču elektroničku preporuku i prodaju (stranice nakladnika na društvenim mrežama). Danas većina velikih nakladnika nudi mogućnost kupnje na svojim mrežnim stranicama (mrežne knjižare), a njihove prednosti u odnosu na fizičke knjižare jesu dostupnost informacija u bilo kojem trenutku i mogućnost pretraživanja knjiga, praćenje preferencija kupaca i moguće ciljno oglašavanje proizvoda putem elektroničke pošte i sl.$^{38}$ Društveni mediji u tom smislu mogu djelovati u ulozi dodatnog promotivno-prodajnog kanala, na kojem se zajednici (bilo na stranicama samog nakladnika na društvenoj mreži ili na nekomercijalnim specijaliziranim stranicama koje prate kretanja na knjižnom tržištu) direktno može plasirati vijest o novim naslovima, promocijama, akcijama i vijestima, uključujući poveznicu koja vodi ka konkretnom proizvodu na stranicama mrežne knjižare, gdje ga je moguće i kupiti.

Promjene nastale pod utjecajem novih tehnologija zahtijevaju prilagodbu poslovanja i marketinške komunikacije novonastaloj situaciji te su marketinški stručnjaci primorani tražiti nove koncepte kojima nastoje razviti i održati bliske odnose s kupcima ${ }^{39}$ Društvene su mreže sve prisutniji komunikacijski kanal koji postaje gotovo neizostavan u komunikaciji nakladničkih kuća, a čija je najveća prednost to što nudi dobru modifikaciju dvosmjerne simetrične komunikacije. ${ }^{40}$ Marketinškim stručnjacima u današnjem informacijskom dobu jasno je da su zbog pojave interneta njihovi potencijalni klijenti izloženi nizu promotivnih poruka uz manjak vremena za istraživanje, zbog čega se sve više okreću usmenoj predaji kroz C2C-modele i društvene mreže. ${ }^{41} \mathrm{~F}$. Pehar navodi pet područja unutar nakladništva kojima koristi primjena društvenih medija u marketinškoj komunikaciji:

- izgradnja brenda usmjerenog prema čitatelju

- usmjeravanje čitatelja od jedne knjige prema drugoj kroz čitateljske klubove

- uključivanje čitatelja u proces pripreme i objave knjige

- praćenje društvenih kritičara i poticatelja prodaje - prikazi/recenzije/ osvrti i

- korištenje novih oblika mjerenja učinka kampanje. ${ }^{42}$

Iz navedenoga je moguće zaključiti kako je virtualno doba ono u kojem se čitatelj knjige nameće kao ključni promotor te iste knjige, a nakladnik je više no

38 Usp. Radalj, M. Nav. dj., str.150-154.

39 Blažević, L. Nav. dj., str. 116.

40 Usp. Radalj, M. Nav. dj., str. 158.

41 Blažević, L. Nav. dj., str. 149.

42 Usp. Pehar, F. Nakladništvo u mreži društvenih medija: novi publikacijski i komunikacijski pristup. // Ppt prezentacija: Sveučilište u Zadru. [citirano: 2018-03-10]. Dostupno na: http://ozk. unizd.hr/wp-content/uploads/2012/05/drustveni_mediji_u_nakladnistvu_dist.pdf. 
ikad prije upućen na komunikaciju s čitateljem, u kojoj je on glasan i ima glavnu riječ koja dopire do velikog broja ostalih čitatelja, odnosno budućih potencijalnih kupaca ${ }^{43} \mathrm{M}$. Radalj zaključuje da knjiga i bez marketinga i odnosa s javnošću i dalje ima snagu komunicirati sa svojom publikom, i to usmenom predajom, odnosno modelom preporuke. ${ }^{44}$ Usmena predaja i danas je osnova mnogih nastojanja u marketingu zbog svog kumulativnog karaktera, što u okvirima nakladništva znači da što čitatelji više govore o knjizi, to je veća mogućnost da informacija o njoj dosegne druge čitatelje, pri čemu se stvara buka (engl. buzz). ${ }^{45} \mathrm{~L}$. Blažević, prema Sernovitzu, objašnjava evoluciju spomenutog modela usmene predaje u nakladništvu iz tradicionalnog oblika u mrežni te navodi kako je ,usmena predaja postala elektronička i oblik marketinga koji najbrže raste, stoga postoji pet glavnih elemenata koje je potrebno uzet u obzir pri stvaranju kampanje elektroničkom preporukom - C2C marketing."

- Izvori informacija: tko će svojim prijateljima i poznanicima govoriti o knjizi?

- Predmet komunikacije: što će izvor informacija govoriti o knjizi?

- Komunikacijski alati: koji će komunikacijski alati biti korišteni u širenju priče o knjizi i može li nakladnik potaknuti to širenje?

- Proces komunikacije: može li se nakladnik i na koji način uključiti u „razgovor“ o knjizi?

- Praćenje: što ljudi zapravo govore o knjizi? ${ }^{46}$

Oslanjajući se na Blaževićevu tezu kako su „društvene mreže najzastupljeniji kanali izravne nakladničke komunikacije“ ${ }^{* 47}$, P. Ljevak uvodi pojam društvenog čitatelja kojeg definira kao konzumenta knjiga koji je ujedno i korisnik digitalnih društvenih mreža ${ }^{48}$ te koji ne želi isključivo i samo knjige nego i pažnju i osobni kontakt s nakladnicima, autorima i čitateljima istomišljenicima. ${ }^{49}$ Društveno čitanje predstavlja čitanje u mrežnom okruženju (uključujući čitanje elektroničkih knjiga), gdje knjiga i čin čitanja daju prednost informacijama zajednice i sredstvima razmjene, a odnosi se na ,tip mrežne platforme ili specifičan program/ aplikaciju koja organizira i čitatelju osigurava prostor za horizontalnu komunikaciju, izmjenu informacija, razmjenu mišljenja o tekstu, sudjelovanje u grupnim

\footnotetext{
43 Tomašević, N. Nav. dj., str. 117.

44 Radalj, M. Nav. dj., str. 110.

45 Thompson, J. B. Merchants of culture. the publishing business in the twenty-first century. Cambridge: Polity Press, 2010. Citirano prema Ljevak, P. Nav. dj., str. 94.

46 Usp. Blažević, L. Nav. dj., str. 149-150.

47 Isto, str. 234.

48 Usp. Ljevak, P. Nav. dj., str. 74.

49 Davis, M.; M. Walter. Next-wave publishing technology. Part 2: Revolutions in process. // Seybold Publications 3, 20(2010), str. 3-21. Citirano prema Ljevak, P. Nav. dj. str. 74.
} 
raspravama i stvaranje i dijeljenje bilješki o knjizi ili autoru".$^{50}$ Snagu i utjecaj čitatelja s pristupom društvenim medijima potvrđuje i činjenica da se potencijalni kupci i čitatelji sve više oslanjaju na iskustva drugih kupaca pri donošenju odluke o kupnji. ${ }^{51} \mathrm{~J}$. Lichtenberg smatra kako pojavom društvenog čitatelja za nakladnike važnima postaje ne samo proizvodnja i prodaja knjiga nego i čitav spektar drugih čimbenika kao što su fleksibilan odnos prema čitateljima, odgovori, učenje i zabava. ${ }^{52} \mathrm{M}$. Jurić istraživao je navike studenata kod čitanja u tiskanom i digitalnom okruženju i došao do zaključka da je čitanje s ekrana ipak manje učinkovito i manje ugodno za čitatelja od tradicionalnog čitanja s papira..$^{53}$ Autor je dodatno došao do spoznaje kako su navike temeljitog čitanja usko vezane uz preferiranje tiskanog okruženja, dok samo digitalno okruženje utječe na stjecanje navike površnog čitanja. ${ }^{54}$ Također, o utjecaju informacijskog okruženja i digitalne tehnologije na procese učenja na uzorku preddiplomskih studenata humanističkih znanosti pisala je S. Dimzov te je došla do spoznaje da je studentima knjiga i dalje primarni informacijski izvor. ${ }^{55}$ Unatoč tomu, autorica je identifikacijom triju faza učenja (pripremna faza, faza učenja i faza ponavljanja i vježbanja) zaključila da je za prvu i posljednju fazu učenja karakteristično to da se odvija uglavnom u grupi i da se pritom koriste digitalni informacijski izvori koje su studenti sami kreirali. S tim se može povezati tvrdnja da studenti danas preferiraju brze informacije, rade više stvari odjednom (u isto vrijeme uče i koriste društvene mreže) i žele raznovrsna iskustva učenja (sami se organiziraju) ${ }^{56}$

Premda je društveni aspekt čitanja potenciran u doba društvenih medija, on postoji odavno, a u prošlosti se uglavnom odvijao kroz interakciju čitatelja u knjižnim klubovima, na javnim čitanjima knjiga, promocijama i predstavljanjima knjiga. ${ }^{57}$ Digitalni oblici knjižnih klubova na društvenim mrežama zapravo su

50 Cordon-Garcia, J. A.; J. Alonso-Arevalo; R. Gomez-Diaz; D. Linder. Social reading: platforms, applications, clouds and tags. Oxford: Chandos Publishing, 2013. Str. 157.

51 Blažević, L. Nav. dj., str 29.

52 Usp. Lichtenberg, J. Thinking outside the book. // Publishers Weekly 246, 41(2000), [citirano: 2017-02-15]. Dostupno na: https://www.publishersweekly.com/pw/print/20001009/23303-mysay-thinking-outside-the-book.html.

53 Usp. Jurić, M. Čitanje u tiskanom i digitalnom okruženju: doktorska disertacija. Zadar: Odjel za informacijske znanosti Sveučilišta, 2017. Str. 183-192. [citirano: 2019-01-12]. Dostupno na: https://bib.irb.hr/datoteka/907122.Juric_Mate_UNIZD_2017_Disertacija-Citanje-u-tiskanom-i-digitalnom-okruzenju.pdf.

54 Isto.

55 Usp. Dimzov, S. Uloga sveučilišne knjižnice u digitalnom okruženju s obzirom na infromacijsko ponašanje studenata humanističkih znanosti: doktorska disertacija. Zadar: Odjel za informacijske znanosti Sveučilišta, 2016. Str. 188-193. [citirano: 2019-01-12]. Dostupno na: https:// dr.nsk.hr/islandora/object/unizd:2038/preview.

56 Isto.

57 Thelwall, M.; K. Kousha. Goodreads: a social network site for book readers. // Journal of the Association for Information Science and Technology 68, 4(2017), 972-983. DOI: https://doi. 
nadograđeni tradicionalni knjižni klubovi gdje čitatelji, bez obzira na kulturnu, socioekonomsku ili geografsku pozadinu, spol ili dob, razmjenjuju preporuke i razgovaraju o knjigama. ${ }^{58}$ Tradicionalni oblici dvosmjerne komunikacije na relacijama čitatelj-čitatelj i čitatelj-nakladnik/autor/prevoditelj/urednik, poput knjižnih klubova, organizirani su od strane nakladnika s ciljem jačanja lojalnosti nakladniku i stvaranja osjećaja prisnosti i pripadnosti. Danas knjižni klubovi od članova rijetko zahtijevaju plaćanje članarine ili kupnju knjige u određenom razdoblju, dok s druge strane nude niz pogodnosti poput popusta, direktne komunikacije s nakladnikom i ljudima sa sličnim interesima. ${ }^{59}$ Iako su u odnosu na novonastale knjižne zajednice na društvenim medijima tradicionalni knjižni klubovi manje praktični jer zahtijevaju veći angažman za sudjelovanje (odlazak na određeno mjesto u određeno vrijeme), oni ipak nude neke pogodnosti koje društveni mediji nemaju, poput posudbe knjige za čitanje, mogućnosti pregledavanja i prelistavanja knjige te fizičkog kontakta s istomišljenicima u stvarnom svijetu.

U kontekstu društvenog čitatelja u digitalnom okruženju javlja se pojam korisničkog sadržaja (engl. user generated content) koji bi u okvirima nakladništva bio definiran kao mrežne informacije stvorene, prenošene i korištene od strane čitatelja u svrhu educiranja drugih čitatelja o knjigama, naslovima, autorima i nakladnicima.$^{60} \mathrm{Tu}$ se podrazumijevaju razni blogovi i stranice o knjigama osnovane od strane čitatelja na kojima oni ostavljaju vlastite recenzije i osvrte na objavljene naslove te na taj način šire informacije o knjigama, potiču komunikaciju i komentiranje s drugim čitateljima i korisnicima društvenih medija. Ovisno o njihovu utjecaju i broju pratitelja, oni imaju mogućnost elektroničkom preporukom pokrenuti pozitivnu komunikaciju o knjizi, ali i stvoriti negativnu buku na koju nakladnik ne može utjecati direktno, nego može isključivo pratiti komentare i pokušati brzom, smirenom i ispravnom reakcijom negativnu komunikaciju usmjeriti u pozitivnom smjeru.

Važnost društvenih medija i interneta u nakladništvu ističe Hilts, koji se u članku objavljenu u magazinu Publishers Weekly osvrće na najvažnije zaključke konferencije „Publishing Direct: Connecting to the Consumer“, održane u studenome 1999. u New Yorku, na kojoj je istaknuto da internet omogućuje najizravniju vezu s potrošačima. Na konferenciji je zaključeno da će najuspješniji biti oni nakladnici koji se koriste novim alatima i zadovoljavaju potrebe potrošača ${ }^{61}$ Porast značaja

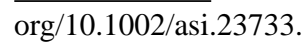

58 Sedo, D. R. Reading Communities from Salons to Cyberspace, Basingstoke: Palgrave Macmillan, 2011., str. 8.

59 Usp. Radalj, M. Nav. dj., str. 169-171.

60 Usp, Blackshaw, P.; M. Nazzaro. Consumer-generated media (CGM) 101: word-of-mouth in the age of the web-fortified consumer. // Nielsen BuzzMetrics (2004). [citirano: 2017-03-12]. Dostupno na: http://www.nielsenonline.com/downloads/us/buzz/nbzm_wp_CGM101.pdf.

${ }_{61}$ Usp. Hilts, P., Direct marketing guru: publishers must use web to find new markets. // Publishers Weekly 246, 48(1999).[citirano: 2017-03-12]. Dostupno na: https://www.publishersweekly. 
društvenih medija u marketinškoj komunikaciji nakladnika u svijetu potvrđuje i autorica Tan u članku objavljenu u magazinu Publishers Weekly, gdje navodi kako su se nakladnici dječje knjige u Kini okrenuli novom načinu oglašavanja i povezivanja s potrošačima kroz tzv. treću platformu, gdje se udružuju društveni mediji, mobilno i cloud-računalstvo i analitika. ${ }^{62}$ Marketing na društvenim medijima pokazao se izrazito uspješnim jer kroz njega elektronička preporuka doseže potpuno novu razinu - zajednice na društvenim medijima imaju značajan utjecaj na svoje „,pratitelje“ i prijatelje, uz napomenu da je u ovom modelu ključna dobra identifikacija najvažnijih vođa mišljenja u ciljnom polju.$^{63}$ Najuspješnije marketinške kampanje u nakladništvu koriste kombinirano tradicionalne elemente promocije (promocije, predstavljanja i potpisivanja knjiga, sajmovi knjiga, osobna prodaja, publicitet u tiskovinama) i suvremene elemente promocije putem interneta i društvenih medija (specijalizirani web-portali, mrežne knjižare, društvene mreže, književni video, kombinacija blogera koji će napisati recenziju knjige itd.). ${ }^{64}$

\subsection{Marketing hrvatskih nakladnika - dosadašnja istraživanja}

U Hrvatskoj se knjigom i nakladništvom te marketingom i odnosima s javnošću u sektoru nakladništva posljednjih godina bavilo nekoliko autora, poput L. Blaževića ${ }^{65}$, P. Ljevak ${ }^{66}$, M. Radalja ${ }^{67}$, N. Tomašević ${ }^{68}$ i D. Živković. ${ }^{69}$ O nedovoljnoj usredotočenosti hrvatskih nakladnika na marketinšku komunikaciju govore rezultati istraživanja koje je L. Blažević proveo tijekom 2015. godine, a na osnovi kojeg zaključuje kako čak 27 \% nakladnika u Hrvatskoj nema strateški marketinški plan te marketinške aktivnosti provodi nasumce, što je posljedica činjenice da su prodaja i promocija svrstane kao najmanje važne kategorije u poslovanju nakladnika. ${ }^{70}$ Autor u svom istraživanju navodi da $70 \%$ hrvatskih nakladnika ipak primjenjuje ogla-

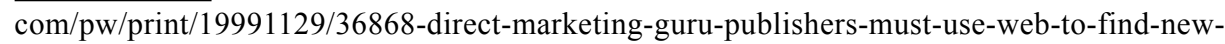
markets.html.

${ }^{62}$ Usp. Tan, T. Children's books in China 2017: Social media marketing takes center stage. // Publishers Weekly, 264, 12(2017). [2018-02-20]. Dostupno na: https://www.publishersweekly. $\mathrm{com} / \mathrm{pw} /$ by-topic/international/international-book-news/article/73096-children-s-books-in-china-2017-social-media-marketing-takes-center-stage.html.

63 Radalj, M. Nav. dj., str. 158-162.

${ }_{64}$ Usp. Byle, A. Building buzz with social media. // Publishers Weekly, 259, 7(2012). [citirano: 2018-02-22]. Dostupno na: https:/www.publishersweekly.com/pw/by-topic/industry-news/religion/article/50571-building-buzz-with-social-media.html.

${ }^{65}$ Blažević, L. Nav. dj.

66 Ljevak, P. Nav. dj.

67 Radalj, M. Nav. dj.

68 Tomašević, N. Istraživanje stajališta o čitanju i njihov utjecaj na nakladništvo: (ocjena zainteresiranosti za književne vrste). // Libellarium 1, 2(2008), 221-241.

69 Živković, D. Nav. dj.

70 Usp. Blažević, L. Nav. dj. str., 75-76. 
šavanje na društvenim mrežama. ${ }^{71}$ Dominantna društvena mreža je Facebook $(83$ \%), slijedi ga Twitter (33\%), dok $17 \%$ nakladnika nije imalo profil na društvenim mrežama u trenutku kad je istraživanje provedeno. ${ }^{72}$ Sudeći prema spomenutom, hrvatski su nakladnici svjesni važnosti i prednosti društvenih medija u marketinškoj komunikaciji prema ciljnom tržištu. Prema N. Tomašević, osnovne odlike velikih hrvatskih nakladnika u elektroničkom segmentu marketinga mogu se grupirati u sljedećim točkama: nakladnici posjeduju vlastite mrežne stranice izrađene isključivo za domicilne kupce, koje imaju dvostruku ulogu - informativnost i e-prodaju - dok upitnici oglašeni na mrežnim mjestima upućuju na slabu analizu ponašanja posjetitelja, knjige na mrežnim mjestima oglašavaju koristeći anotacije, recenzije i izvatke iz tiska. ${ }^{73}$ Nadalje, u okviru „marketinga prema mnogima“ $u$ hrvatskom nakladništvu uočava se komunikacija putem mrežnih skupina razvijenih od strane nakladnika ili krajnjih korisnika, putem književnih blogova i na forumima. ${ }^{74}$

Istraživanje tržišta knjige u Hrvatskoj na godišnjoj razini provodi GfK Hrvatska, s fokusom na navikama čitanja i kupnje knjiga. Prema istraživanju iz 2018. godine, knjižare i dalje ostaju dominantan kanal prodaje knjiga (u njima se ostvaruje više od polovice prodaje - $54 \%$ ), nakon čega dolaze kiosci (13\%) te mrežne knjižare $(12 \%){ }^{75}$ Nadalje, $72 \%$ ispitanika ima mogućnost čitanja na elektroničkim medijima (računalo $-61 \%$, pametni telefon $-50 \%$, tablet $-19 \%$, e-čitač -2 \%). ${ }^{76}$ Navedeno istraživanje ukazuje na potencijal mrežnih knjižara i društvenih medija kao mjesta okupljanja zaljubljenika u knjige, gdje se virtualno mogu odvajati razne aktivnosti - od informiranja o knjigama i događanjima na tržištu knjige, preko komentiranja pročitanih knjiga, do kupnje i čitanja knjiga u elektroničkom formatu. M. Radalj u svojem je istraživanju došao do zaključka da svi nakladnici iz kategorije velikih nakladnika imaju mrežne knjižare i profil na najmanje jednoj od društvenih mreža. ${ }^{77}$ Većina nakladnika koristi društvene mreže istovremeno kao komunikacijski i prodajni kanal, dok se u svrhu oglašavanja $83 \%$ nakladnika prvenstveno okreće publicitetu, a tek $17 \%$ zakupljuje oglasni prostor u medijima. ${ }^{78}$ Iako je elektronička preporuka format informiranja kojem korisnici najviše vjeruju, hrvatski nakladnici ne posvećuju joj dovoljno pozornosti (samo $33 \%$ nakladnika obuhvaćenih istraživanjem koje je autor proveo 2015. godine kontrolira i usmjerava preporuke na webu). ${ }^{79} \mathrm{P}$. Ljevak potvrdila je istraživanjem društvenog

\footnotetext{
71 Isto, str. 124.

72 Isto.

74 Isto. ge 23.04.2018.

76 Isto.

77 Usp. Radalj, M. Nav. dj., str. 154-160.

78 Blažević, L. Nav. dj., str. 152.

79 Isto.
}

73 Usp. Tomašević, N. Kreativna. Nav. dj., str. 113-115.

75 Usp. Kraus, T. Istraživanje tržišta knjiga u Hrvatskoj. Zagreb: GFK Hrvatska, 2018. [citirano: 2019-01-16]. Dostupno na: https://issuu.com/modernavremena/docs/prezentacija_no_knji- 
čitatelja u okvirima Hrvatske ,postojanje novog tržišta namijenjenog nakladničkom proizvodu čije su komunikacijske navike uvjetovane karakteristikama Weba 2.0 i društvenih medija“"80, što opravdava potrebu korištenja društvenih medija i marketinga elektroničkom preporukom od strane nakladnika u svrhu širenja informacija o novim (i starim) knjigama i aktivnostima vezanim uz knjigu te s ciljem poticanja kulture čitanja.

Kontekst participativnog interneta mijenja način rada nakladničkog sektora jer jača uloga korisnika koji također postaju kreatori digitalnih kulturnih sadržaja. Razvoj tehnologije, široka dostupnost interneta te popularizacija društvenih medija i elektroničke preporuke utječu na promjene načina komuniciranja ljudi na privatnoj i poslovnoj razini, što se preslikava i na samo tržište knjige, rezultirajući promjenama čitateljskih navika i kontinuiranim mijenjanjem same aktivnosti čitanja. Čitanje se iz tradicijski primarno individualne aktivnosti širi u digitalnu sferu i poprima društvenu dimenziju koja se u odnosu na tradicionalne oblike društvenog čitanja (knjižne klubove, promocije i sl.) širi na nepoznate čitatelje, a nerijetko i na osobe uključene u proces nastanka knjige, poput autora ili izdavača. Sve su češća pojava i korisnički sadržaji na društvenim medijima stvoreni i prenošeni od strane čitatelja u svrhu iskazivanja vlastitih stavova o knjigama drugim čitateljima (razni blogovi i stranice o knjigama). Mogućnost lake uspostave virtualnih resursa znači da danas svatko s dovoljno motivacije i entuzijazma može pokrenuti vlastiti web-portal, blog, stranicu na nekoj od društvenih mreža i sl. Ipak, dugoročna održivost takvih projekata nije ovisna samo o tehnološkoj bazi već i o dobro promišljenoj ideji, identificiranim korisnicima i osiguranim materijalnim resursima. Izdavači s ciljem privlačenja što većeg broja čitatelja stoga svoje marketinške aktivnosti sele na društvene medije, mrežne knjižare postaju obvezan dio poslovanja, a stvaranje i održavanje odnosa s vođama mišljenja dobiva važnu ulogu u cjelokupnom promocijskom spletu izdavača. Hrvatsko tržište knjige donekle prati novonastale trendove, iako nesumnjivo postoji dosta prostora za poboljšanje. Naposljetku, kako zaključuje J. B. Thompson naglašavajući važnost strateške komunikacije prema čitateljima, „dobar nakladnik nije onaj koji izdaje knjige (što je danas lako), nego onaj koji se uspije izboriti za pažnju čitatelja i stvoriti čitateljsku publiku“ ${ }^{81}$ Prema tome, potreba za korištenjem društvenih medija i poticanjem marketinga elektroničkom preporukom u svrhu širenja kulture čitanja je evidentna, što ukazuje na važnost kontinuirane prilagodbe marketinških strategija hrvatskih nakladnika novonastalom profilu suvremenog društvenog čitatelja te implicira potrebu detaljnijeg proučavanja mogućnosti koje nudi elektronička preporuka i njezina uključivanja u aktivnosti marketinške komunikacije od strane izdavača.

80 Ljevak, P. Nav. dj., str. 231.

${ }_{81}$ Usp. Thompson, J. B. Nav. dj. Citirano prema Ljevak, P. Nav. dj. str. 91. 


\section{Istraživanje}

Istraživanje provedeno strukturiranim anketnim upitnikom na prosudbenom namjernom uzorku od 20 nakladničkih poduzeća obuhvatilo je 13 malih nakladnika koji su tijekom 2015., 2016. i 2017. godine objavili 14 ili manje naslova godišnje, 3 srednja nakladnika koji su tijekom promatranih godina objavili između 15 i 29 naslova godišnje te 4 velika nakladnika koji su tijekom promatranih godina objavili 30 ili više naslova godišnje (prikaz u tablici 1).

Tablica 1. Prikaz nakladnika obuhvaćenih istraživanjem po kategorijama

\begin{tabular}{|c|c|c|c|c|}
\hline & $\begin{array}{l}\text { Mali } \\
\text { nakladnici }\end{array}$ & $\begin{array}{l}\text { Srednji } \\
\text { nakladnici }\end{array}$ & $\begin{array}{l}\text { Veliki } \\
\text { nakladnici }\end{array}$ & Ulapue \\
\hline \multicolumn{5}{|c|}{ Broi zaposlenih u poduzeću } \\
\hline 1-9 zaposlenika & 11 & 2 & 0 & 13 \\
\hline 10-24 zaposlenika & 1 & 1 & 0 & 2 \\
\hline 25-49 zaposlenika & 1 & 0 & 2 & 3 \\
\hline Preko 50 & 0 & 0 & 2 & 2 \\
\hline UTupno & 13 & 3 & 4 & \\
\hline \multicolumn{5}{|c|}{ Osnorna djelatnost } \\
\hline Nakiadnistuo & 13 & 3 & 4 & 20 \\
\hline Maloprodaja & 1 & 0 & 2 & 3 \\
\hline Tiskarska djelatnost & 0 & 0 & 2 & 2 \\
\hline Ukupno & 14 & 3 & 8 & \\
\hline \multicolumn{5}{|c|}{ Broj zaposlenih u odjelu marketinga } \\
\hline 1-2 zaposlenika & 2 & 2 & 3 & 9 \\
\hline 3-5 zaposienila & 0 & 0 & 1 & 1 \\
\hline $\begin{array}{l}\text { Nema fomiran odjel marketinga } \mathrm{i} \\
\text { PR-a }\end{array}$ & 11 & 1 & 0 & 12 \\
\hline Uhupno & 15 & 6 & 4 & \\
\hline \multicolumn{5}{|c|}{ Odjel u kojem je ispitanik zaposlen } \\
\hline Marketing/PR & 2 & 1 & 4 & 7 \\
\hline Uredništvo/redakcija & 5 & 1 & 0 & 6 \\
\hline Prodaja & 6 & 1 & 0 & 7 \\
\hline Uhupno & 13 & 3 & 4 & \\
\hline
\end{tabular}

Istraživanjem je obuhvaćeno 14 nakladnika koji se bave isključivo nakladništvom, 4 nakladnika koji se uz nakladništvo bave i maloprodajom te 2 nakladnika koji uz nakladništvo i maloprodaju imaju i tiskarsku djelatnost. Maloprodajom i tiskarskom djelatnošću uz nakladništvo uglavnom se bave veliki nakladnici, nešto manje srednji nakladnici, dok je iz kategorije malih samo jedan nakladnik naveo da se uz nakladništvo bavi i maloprodajom. Sveukupno 8 ispitanih nakladnika ima formiran odjel marketinga, i to nakladnici iz kategorija velikih i srednjih te 2 nakladnika iz kategorije malih, dok je dvanaest ispitanih nakladnika potvrdilo da nema formiran sektor marketinga (među njima je 11 nakladnika iz kategorije malih i 1 na- 
kladnik iz kategorije srednje velikih) te marketinške aktivnosti obavlja unutar odjela prodaje. Među ispitanicima obuhvaćenim anketom 7 je iz sektora marketinga, 7 iz sektora prodaje, dok je preostalih 6 ispitanika zaposleno u uredništvu.

\subsection{Društveni mediji kao dio marketinške komunikacije nakladnika}

Kako bi se utvrdilo u kojoj mjeri hrvatski nakladnici u marketinškoj komunikaciji koriste digitalne alate oglašavanja te koji je odnos udjela tradicionalnog oglašavanja, internetskog oglašavanja (prikazno oglašavanje, oglašavanje na tražilicama, kontekstualno oglašavanje, mobilno oglašavanje) i publiciteta u tisku i društvenim medijima, nakladnicima je postavljeno pitanje na koje se kanale oglašavanja uglavnom fokusiraju u vlastitim marketinškim i oglašivačkim kampanjama. Od ispitanika je zatraženo da za svaki pojedini tip oglašavanja označe u kojoj ga mjeri koriste ( 1 - nikad, 2 - rijetko, 3 - ponekad, 4 - često, 5 - uvijek). Istraživanje je pokazalo da nakladnici vlastite marketinške napore uglavnom usmjeravaju na publicitet - kroz tiskovine (70 \% nakladnika koristi ih često ili uvijek) te kroz društvene medije ( $65 \%$ nakladnika uvijek ili često primjenjuje taj model oglašavanja). Slijedi plaćeno oglašavanje na društvenim medijima, dok se najmanje koristi plaćeno oglašavanje na televiziji ili radiju. Grafički prikaz prosječne ocjene i medijana dobivenih rezultata prikazan je na slici 1 .

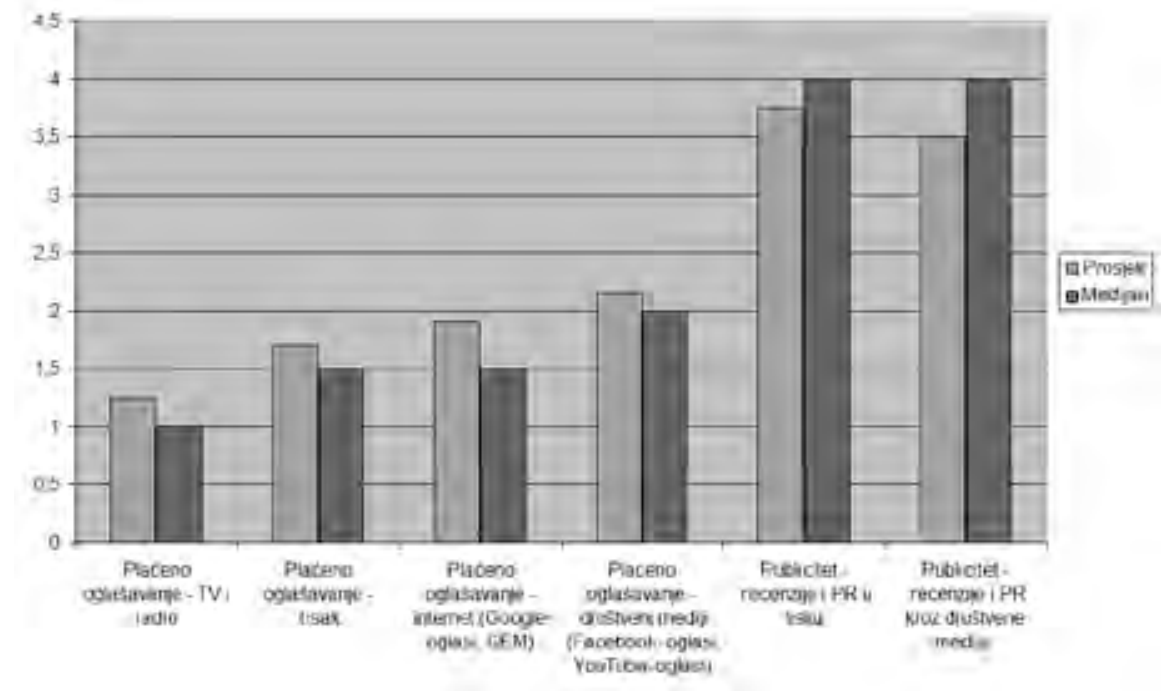

Slika 1. Učestalost pojedinih tipova oglašavanja u marketinškoj komunikaciji hrvatskih nakladnika - prosjek i medijan 
Kako bi se dobila detaljnija slika o korištenju društvenih medija u marketinškoj komunikaciji među hrvatskim nakladnicima, ispitanicima je postavljeno pitanje koriste li društvene medije. Svi ispitani nakladnici naveli su da koriste društvene medije (društvene mreže, blogove, YouTube i sl.) za potrebe marketinške komunikacije. Nadalje, od ispitanika je zatraženo da označe na kojim društvenim mrežama imaju aktivan poslovni profil koji koriste u svrhu marketinške komunikacije najmanje jednom mjesečno (slika 2).

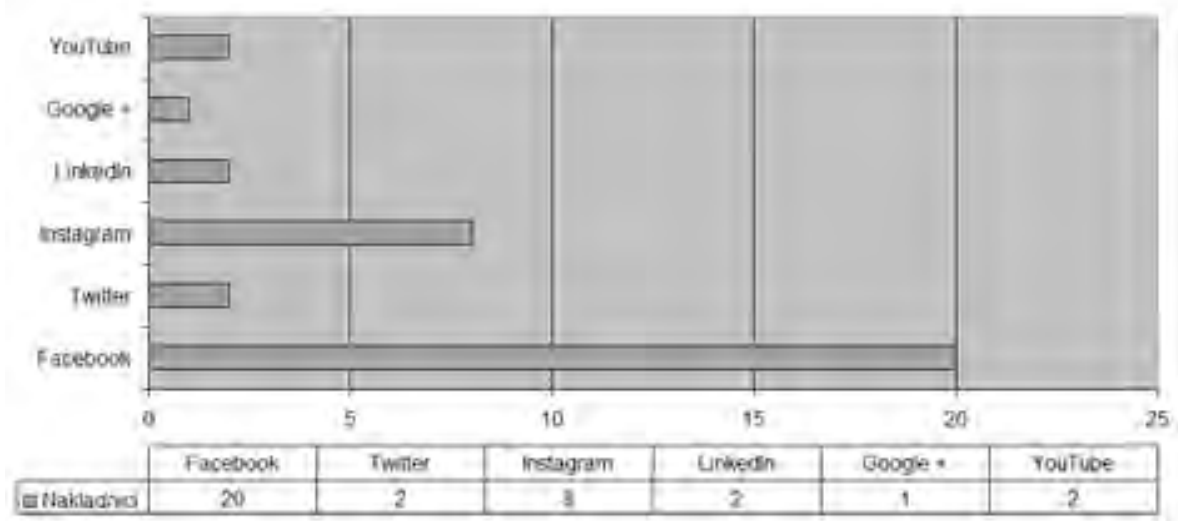

Slika 2. Nakladnici s aktivnim poslovnim profilom na društvenim mrežama

Dobiveni rezultati ukazuju na iznimnu popularnost društvene mreže Facebook, za koju je svih 20 ispitanika potvrdilo prisutnost. Slijedi ju Instagram (8 nakladnika), dok je prisutnost nakladnika na ostalim društvenim mrežama zanemariva.

\subsection{Elektronička preporuka}

Na pitanje o poznavanju pojma elektroničke preporuke, koji se smatra produžetkom usmene predaje, a definiran je kao ,javna izmjena mišljenja, putem elektroničkog medija, među ljudima koji se u pravilu nikada nisu upoznali i ni na koji način nisu društveno povezani“"82, 13 nakladnika odgovorilo je potvrdno (65\%). Svi veliki nakladnici upoznati su sa spomenutim pojmom, dok dvije trećine srednjih nakladnika ( 2 od 3 ) i trećina malih nisu upoznati s pojmom elektroničke preporuke. Važnost elektroničke preporuke u marketinškoj komunikaciji potvrdilo je 13 ispitanih nakladnika (65\%), dok je važnost suradnje s neovisnim web-portalima, blogerima i Facebook-grupama koje prate kretanja na hrvatskom književnom tržištu potvrdilo 16 nakladnika ( 80 \%). Odnos važnosti spomenutih elemenata prema mišljenju hrvatskih nakladnika prikazan je na slici 3.

82 O’Reilly, K.; A. MacMillan; A. G. Mumuni; K. Lancendorfer. Nav. dj., str. 96. 


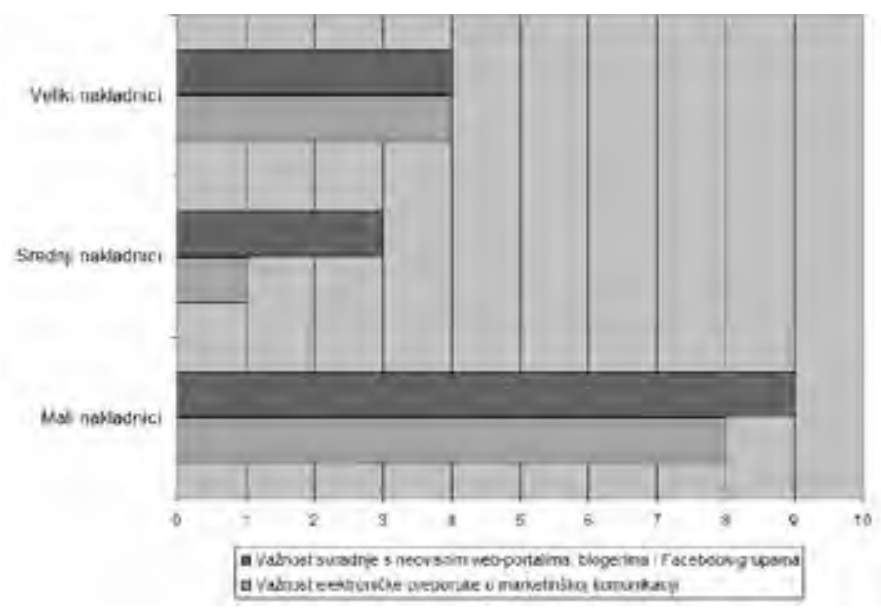

Slika 3. Važnost elektroničke preporuke i suradnje s vođama mišljenja

Na pitanje surađuju li s vođama mišljenja 17 nakladnika dalo je potvrdan odgovor $(85 \%)$. Taj rezultat, skupa s činjenicom da hrvatski nakladnici koriste društvene medije u svrhu marketinškog oglašavanja i imaju aktivan poslovni profil na najmanje jednoj društvenoj mreži, potvrđuje da hrvatski nakladnici koriste marketinški model elektroničke preporuke. U nastavku na slici 4 prikazani su aritmetička sredina i medijan ocjene stava nakladnika o utjecaju suradnje s blogerima i urednicima neovisnih društvenih web-portala na pojedine elemente poslovanja. Nakladnici su za svaki pojedini element poslovanja označili svoj stav o pozitivnom utjecaju suradnje s vođama mišljenja na ljestvici od 1 do 5 (1 - uopće se ne slažem, 2 - ne slažem se, 3 - niti se slažem niti se ne slažem, 4 - slažem se, 5 - potpuno se slažem).

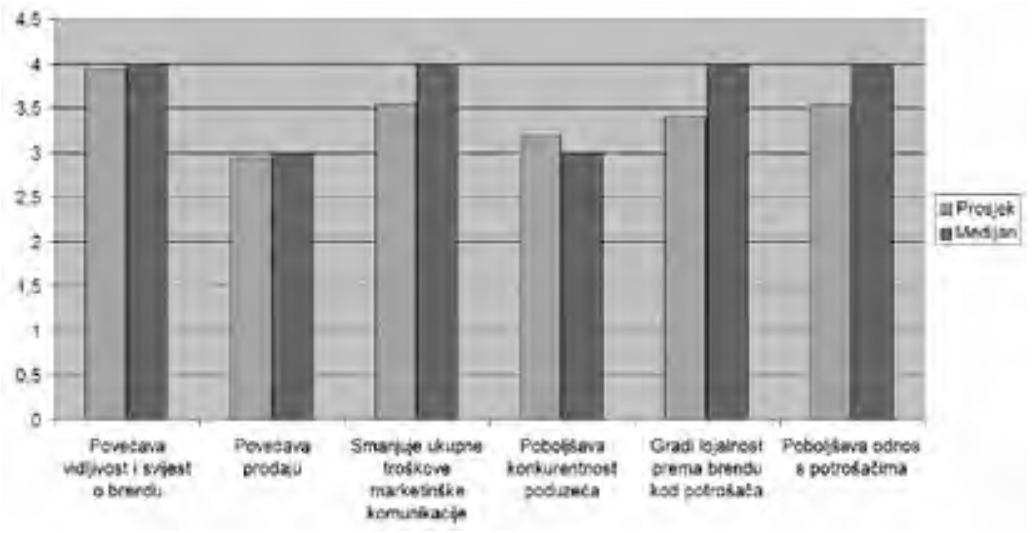

Slika 4. Stav nakladnika o utjecaju suradnje s nekomercijalnim elektroničkim medijima na pojedine elemente poslovanja - prosjek i medijan 
Nakladnici obuhvaćeni istraživanjem uglavnom se slažu da suradnja s vođama mišljenja, odnosno nekomercijalnim medijima kao što su specijalizirani web-portali, blogovi i stranice na društvenim mrežama, pozitivno utječe na njihovo poslovanje. Pritom se slažu da taj tip suradnje ima najznačajniji utjecaj na povećanje vidljivosti i svijesti o brendu i proizvodima (prosječna ocjena 3,95; medijan 4) te da ujedno doprinosi i smanjenju ukupnog troška marketinške komunikacije (ocjena 3,55; medijan 4), poboljšava odnos s potrošačima (ocjena 3,55; medijan 4) te gradi lojalnost brendu (ocjena 3,4; medijan 4). Utjecaj na konkurentnost poduzeća i povećanje prodaje nije primjetan (ocjena 3,2; medijan 3 za element konkuretnosti te 2,95; 3 za povećanje prodaje). Na kraju anketnog upitnika od ispitanika je zatraženo da označe u kojoj mjeri različiti tipovi oglašavanja prema njihovu mišljenju utječu na odluku čitatelja o kupnji ili čitanju knjige (1 - uopće ne utječe, 2 - uglavnom ne utječe, 3 - niti utječe niti ne utječe, 4 - uglavnom utječe, 5 - iznimno utječe). Grafički prikaz dobivenih rezultata nalazi se na slici 5.

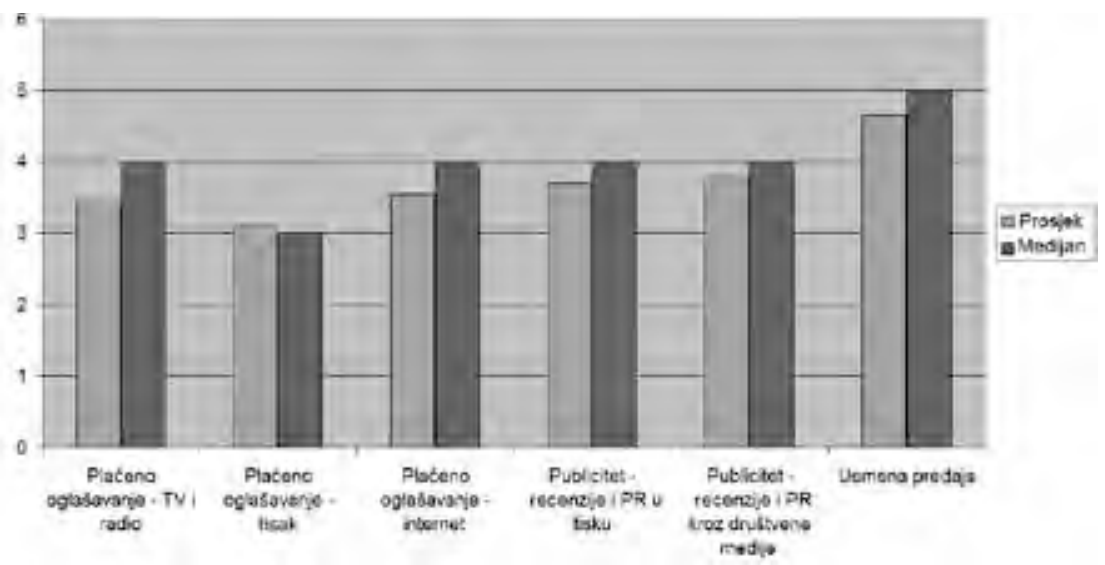

Slika 5. Stav nakladnika o utjecaju različitih elementa marketinške komunikacije na donošenje odluke o kupnji/čitanju knjige - prosjek i medijan

Nakladnici su, u skladu s očekivanjima, najutjecajnijim ocijenili najstariji element marketinške komunikacije - usmenu predaju (prosječna ocjena 4,65; medijan 5), pa polovica ispitanika smatra da ona iznimno utječe na odluku od kupnji ili čitanju knjige. Publicitet kroz društvene medije, odnosno elektroničku preporuku (prosječna ocjena 3,8; medijan 4) i publicitet u tiskovinama (prosječna ocjena 3,7; medijan 4) polovica ispitanika smatra uglavnom i iznimno utjecajnima. Elemente plaćenog oglašavanja - televiziju i radio (prosječna ocjena 3,45; medijan 4) te internet (prosječna ocjena 3,55; medijan 4) ocijenili su nešto manje utjecajnima, no i dalje važnima, dok je plaćeno oglašavanje u tiskovinama, u odnosu na ostale ponuđene oblike promocije, ocijenjeno kao najmanje utjecajno među ponuđenim elementima promocije (prosječna ocjena 3,1; medijan 3). 


\section{Rasprava}

Zahvaljujući suvremenim alatima društvenih medija koji su jednostavni i prilagođeni korisniku, komunikacija na internetu danas poprima potpuno nov oblik. Količina sadržaja eksponencijalno raste: sadržaji se pojavljuju kroz blogove, web-stranice i razne društvene mreže, mogućnost razmjene i dijeljenja sve je jednostavnija, a korisnici se pozivaju na razmjenu mišljenja i komentara te na sudjelovanje u kreiranju. Posljedica digitalizacije jesu i velike promjene u marketinškoj komunikaciji nakladnika, gdje se neizostavno moraju uzeti u obzir čitatelji koji pojavom društvenih medija umjesto uloge pasivnog promatrača preuzimaju ulogu aktivnog sudionika i sukreatora mišljenja. Tako nekad anonimni čitatelj, čije mišljenje o knjizi nije dosezalo dalje od kruga njegovih poznanika, u novom okruženju postaje komentator, kritičar i promotor, a njegovo mišljenje i stav dobivaju na težini jer postaju dostupni milijunima drugih korisnika. U okvirima marketinške komunikacije on prestaje biti isključivo primatelj poruke i preuzima ulogu sudionika u procesu oglašavanja. Na taj način nastaje elektronička preporuka knjige, a čitatelj postaje kreator elektroničke varijante najstarijeg, ali i dalje najutjecajnijeg oblika oglašavanja. Kao posljedica toga javlja se pojam vođa mišljenja (blogera, urednika specijaliziranih neovisnih web-portala ili zajednica na nekoj od društvenih mreža) koji oko sebe okupljaju značajniju zajednicu pratitelja prema kojoj komuniciraju svoje stavove, mišljenja i iskustva te na koju utječu. Uzimajući spomenuto u obzir, marketinški stručnjaci mogu kontrolirano (davanjem informacija o knjizi i slanjem besplatnih probnih primjeraka utjecajnim pojedincima na internetu) poticati konverzaciju o vlastitim naslovima među korisnicima društvenih medija.

U skladu s dosadašnjim istraživanjima elemenata marketinške komunikacije na uzorku hrvatskih nakladnika, provedeno istraživanje ukazalo je na općenit problem nedovoljno razvijenog marketinga i marketinške komunikacije u nakladničkom sektoru. Sektor marketinga ne postoji kod $60 \%$ ispitanih poduzeća, dok je postotak još viši unutar kategorije malih nakladnika (85 \%). Kod tradicionalnog oglašavanja nakladnici su uglavnom usmjereni na publicitet kroz tiskovine, dok je klasično oglašavanje putem televizije i radija te putem tiska gotovo zanemarivo. Isti je slučaj i s publicitetom kroz društvene medije (elektronička preporuka) koji je popularan model oglašavanja kod hrvatskih nakladnika, dok je istovremeno primjena plaćenog oglašavanja putem interneta zanemariva. Odnos plaćenog oglašavanja i publiciteta, kako u tradicionalnim tako i u društvenim medijima, može ukazivati na to da se nakladnici zbog specifičnosti knjige kao kulturnog proizvoda ipak okreću modelu oglašavanja putem preporuka (usmena predaja / pismena predaja - recenzija / elektronička preporuka), no izglednija je pretpostavka da je spomenuti fenomen posljedica nepostojećih budžeta za oglašavanje kod hrvatskih nakladnika, zbog čega se okreću modelu oglašavanja koji ne iziskuje velik trošak. Ipak, bez obzira na razlog, širenje uporabe i jačanja utjecaja društvenih medija 
u području marketinga i odnosa s javnošću nakladničkog sektora zasigurno ima pozitivan predznak. Ranije spomenuto istraživanje koje je provela IAB Croatia $(98,68 \% \text { ispitanika se u tipičnom radnom tjednu koristi internetom })^{83}$ govori u korist dobivenim rezultatima istraživanja i ukazuje na to kako internet na neki način istiskuje tradicionalne medije, što će se u budućnosti vrlo vjerojatno posljedično odraziti i na smanjivanje opsega zakupa oglasnog prostora u tiskanim medijima, a u korist elektroničkih medija u svim ekonomskim sektorima.

Digitalizaciju marketinške komunikacije hrvatskih nakladnika potvrđuje i činjenica da svi nakladnici imaju poslovni profil na najmanje jednoj društvenoj mreži koji koriste u svrhu komunikacije s čitateljima i dijeljenja informacija o novim naslovima, akcijama i sl. Najpopularnija društvena mreža među hrvatskim je nakladnicima Facebook, a slijedi ga Instagram. Hrvatski nakladnici koriste društvene medije u svrhu marketinškog oglašavanja i imaju aktivan poslovni profil na najmanje jednoj društvenoj mreži, a $85 \%$ nakladnika surađuje s neovisnim portalima, blogerima i zajednicama na društvenim mrežama, što ukazuje na to da utjecaj društvenih medija ima značajnu ulogu u okvirima cjelokupnog oglašivačkog miksa nakladničkog sektora. Dobiveni rezultati u skladu su s rezultatima istraživanja koje je 2014. godine proveo L. Blažević, koji je došao do zaključka da je većina hrvatskih nakladnika prepoznala poslovni potencijal upotrebe društvenih mreža i ima svoju stranicu na nekoj od društvenih mreža ${ }^{84} \mathrm{P}$. Ljevak navodi kako prosječan broj korisnika nakladničkih Facebook-stranica nije značajno manji od prosječne dnevne naklade nekih tiskovina, što uz činjenicu da je komunikacija na društvenim medijima besplatna ili popraćena niskim troškovima potvrđuje isplativost korištenja društvenih medija (konkretno, Facebooka) u marketinškoj komunikaciji nakladnika. ${ }^{85}$

Najsnažniji element marketinške komunikacije na društvenim medijima nesumnjivo je elektronička preporuka, koja je u modernoj marketinškoj komunikaciji često istraživana od strane niza autora. To nije neobično s obzirom na sve veći broj dokaza kako „potrošači sve češće koriste društvene medije u vlastitim odlukama o kupnji“"86, odnosno „preko $90 \%$ korisnika interneta čita recenzije i preporuke drugih korisnika, a $89 \%$ tvrdi da one utječu na njihovu odluku o kupnji“. ${ }^{87} \mathrm{~J}$. B. Thompson u svom radu naglašava kumulativni karakter usmene predaje, koji se preslikava i na elektroničku preporuku ${ }^{88}$, a djeluje tako da se, što više čitatelji govore o knjizi (bilo na stranicama nakladnika ili na drugim specijaliziranim

\footnotetext{
83 IAB Croatia. Mediascope. // Iab Croatia, 2015. [2017-03-10]. Dostupno na: http://www. iab-croatia.com/mediascope/.

84 Blažević. L. Nav. dj., str. 124.

85 Ljevak. P. Nav. dj., str. 203.

86 Meuter, M.; D. Brown McCabe; J. Curran. Nav. dj., str. 240.

87 Barreda, A.; A. Bilgihan; Y. Kageyama. Nav. dj., str. 30-31.

${ }^{88}$ Usp. Thompson, J. B. Nav. dj. Citirano prema Ljevak, P. Nav. dj., str. 94.
} 
društvenim medijima koji prate tržište knjiga), povećava vjerojatnost da će se informacija o knjizi širiti i na taj način poticati druge čitatelje da govore o njoj. Tako čitatelji komentiranjem i ocjenjivanjem sadržaja o knjizi postavljenog od strane nakladnika ili vođe mišljenja postaju sudionici marketinške komunikacije. A. Barreda, A. Bilgihan i Y. Kageyama ukazuju na to da izgradnja pozitivne slike brenda na društvenim medijima zahtijeva visok stupanj povjerenja od strane potrošača ${ }^{89}$, odnosno da su korisnici koji su zadovoljni i koji vrednuju pozitivan odnos prema brendu i poduzeću skloni uključivanju u aktivnosti podrške u smislu ostavljanja pozitivne recenzije na webu ili društvenim mrežama. Ispitivanje stava nakladnika o važnosti elektroničke preporuke pokazalo je da $65 \%$ nakladnika taj fenomen smatra važnim elementom svoje marketinške komunikacije, dok čak 80 \% potvrđuje važnost suradnje s neovisnim web-portalima, blogerima i Facebook-grupama koje prate kretanja na hrvatskom književnom tržištu. S obzirom na to da suradnja $s$ vođama mišljenja na društvenim medijima, $s$ ciljem poticanja recenzije ili osvrta na knjigu, predstavlja jedan od tipova elektroničke preporuke, može se zaključiti da gotovo trećina hrvatskih nakladnika, iako nije upoznata s marketinškim pojmom elektroničke preporuke, i dalje shvaća važnost prisutnosti na društvenim mrežama i suradnje s vođama mišljenja. Dobiveni rezultati u skladu su i sa saznanjima koje u svom radu donosi $\mathrm{N}$. Tomašević, koja je uočila da se u elektroničkom marketingu prema mnogima u hrvatskom nakladništvu komunikacija uglavnom odvija putem mrežnih skupina razvijenih od strane nakladnika ili krajnjih korisnika (vođa mišljenja), putem književnih blogova i na forumima. ${ }^{90}$

Istraživanje je također potvrdilo da hrvatski nakladnici primjećuju pozitivan utjecaj oglašavanja putem društvenih medija i elektroničke preporuke. Publicitet putem društvenih medija, odnosno elektronička preporuka, dio je komunikacijskih kampanja većeg broja hrvatskih nakladnika (65\% nakladnika uvijek ili često primjenjuje taj model oglašavanja). Nakladnici smatraju da pozitivne poruke plasirane putem elektroničke preporuke, odnosno preporuke na stranicama vođa mišljenja, preporuke u elektroničkim književnim grupama i na društvenim mrežama, uglavnom imaju pozitivan utjecaj na odluku o kupnji ili čitanju pojedinih naslova. L. Blažević je, suprotno rezultatima dobivenim ovim istraživanjem, u svom radu iz 2015. godine došao do zaključka da hrvatski nakladnici ne posvećuju dovoljno pozornosti elektroničkoj preporuci dobivši rezultat od tek 33\% nakladnika koji kontroliraju i usmjeravaju usmenu predaju na webu.${ }^{91}$ Razlika u dobivenim rezultatima može biti posljedica različitog odabira uzorka istraživanja, no izgledna je i mogućnost da su hrvatski nakladnici tijekom tri godine koje su protekle od istraživanja koje je proveo L. Blažević počeli primjećivati važnost društvenih medija i pozitivne učinke elektroničke preporuke na njihovo poslovanje. U korist

89 Usp. Barreda, A.; A. Bilgihan; Y. Kageyama. Nav. dj., str. 30-31.

90 Usp. Tomašević, N. Nav. dj., str. 113-115

91 Usp. Blažević, L. Nav. dj., str. 152. 
navedene pretpostavke govore i rezultati ispitivanja stava nakladnika o učinku primjene elektroničke preporuke na pojedine segmente poslovanja. Hrvatski nakladnici smatraju da elektronička preporuka povećava vidljivost knjige i podiže svijest o knjizi, poboljšava odnos s čitateljima, smanjuje ukupne troškove marketinške komunikacije i gradi lojalnost prema brendu. Rezultati istraživanja stoga potvrđuju da su nakladnici svjesni pozitivnih učinaka korištenja elektroničke preporuke i društvenih medija na status i vidljivost njihovih proizvoda, ali i cijelog poduzeća, zbog čega se može pretpostaviti da taj tip oglašavanja svakako ima velik potencijal dodatnog razvoja u budućnosti i širenja na cjelokupan nakladnički sektor.

S obzirom na način provođenja istraživanja, potrebno je naglasiti da postoje određena ograničenja koja proizlaze iz njega. Riječ je o prosudbenom namjernom uzorku, zbog čega je nemoguće na osnovi dobivenih rezultata izvoditi zaključke o cjelokupnom nakladničkom tržištu u Hrvatskoj. Nadalje, premda su autori koji su se posljednjih godina bavili istraživanjem marketinške komunikacije u okvirima hrvatskog nakladničkog tržišta (L. Blažević i M. Radalj), zbog činjenice da mali broj nakladnika objavljuje više od $50 \%$ sveukupnog broja knjiga na tržištu, u svojim istraživanjima za uzorak odabrali jednak broj malih, srednjih i velikih nakladnika, u radu je napravljen odmak od navedenih istraživanja te je struktura uzorka u njemu u skladu sa stvarnom strukturom nakladničkog tržišta. Tim pristupom nastaje moguće ograničenje u istraživanju marketinške komunikacije zbog činjenice da mali nakladnici uglavnom nemaju formirane sektore marketinga, zbog čega marketinške aktivnosti mogu biti ograničene, a poznavanje marketinških pojmova i elemenata umanjeno. U tom smislu provedeno istraživanje može poslužiti kao smjernica za dublju analizu elektroničke preporuke i upotrebe društvenih medija u marketinškoj komunikaciji onih nakladnika koji imaju formirane marketinške sektore. Također, ovo istraživanje iznosi stav nakladnika prema društvenim medijima i elektroničkoj preporuci te bi se sljedeća istraživanja tog fenomena mogla okrenuti prema čitatelju kao primatelju poruke i istražiti koji kanali i tipovi komunikacije i marketinške poruke imaju najveći utjecaj na njih.

\section{Zaključak}

Istraživanje provedeno na uzorku od dvadeset hrvatskih nakladnika potvrdilo je da se trend digitalizacije marketinške komunikacije te porasta važnosti i utjecaja društvenih medija preslikava i na tržište knjige u Hrvatskoj, na kojem se također može primijetiti značajnija orijentacija prema digitalnom marketingu, oglašavanju na društvenim mrežama i izgradnji partnerskog PR-odnosa s vođama mišljenja, a samim time i prema korištenju elektroničke preporuke. U okvirima hrvatskog tržišta knjige danas postoji desetak značajnijih web-stranica, blogova i zajednica na društvenim mrežama koje prate knjigu i niz manjih blogova i zajednica na društvenim mrežama koje okupljaju nešto manji broj pratitelja. Većina nakladnika po- 
vremeno surađuje s vođama mišljenja, dok manji dio nakladnika potvrđuje čestu suradnju sa spomenutim društvenim medijima. Nakladnici se slažu s time da su prisutnost i publicitet $u$ društvenim medijima važan dio njihove cjelokupne marketinške komunikacije te da oni uglavnom imaju pozitivan učinak na vidljivost i svijest o brendu i proizvodima kod potrošača, a ujedno i na smanjenje ukupnih marketinških troškova te na izgradnju lojalnosti brendu. Nakladnici se također slažu s time da je usmena predaja i dalje najsnažniji oblik marketinške komunikacije te da je nadmoćna u odnosu na sve ostale elemente oglašavanja. S obzirom na značajan utjecaj društvenih medija, sve veći postotak vremena koje korisnici provode na društvenim medijima te jasnu superiornost usmene predaje kao elementa marketinške komunikacije u nakladničkom sektoru, očigledno je da se budućnost uspješne marketinške komunikacije skriva u učinkovitoj primjeni modela elektroničke preporuke. Spomenuto implicira potrebu za dubljim istraživanjem mogućnosti koje nudi elektronička preporuka, kao i za prilagodbom i uklapanjem njezina pravog oblika i omjera u marketinšku komunikaciju.

$\mathrm{Na}$ temelju rezultata dobivenih provedenim istraživanjem može se pretpostaviti da u nakladničkom sektoru postoji težnja za praćenjem trendova u marketinškoj komunikaciji i prilagodbom marketinških strategija promjenjivoj slici medijskog svijeta. Također, izgledno je da će važnost društvenih medija, vođa mišljenja i, općenito, elektroničke preporuke u nakladničkom području rasti u skladu s promjenama i prilagodbom marketinških strategija koje će se (s ciljem postizanja uspjeha i učinkovitosti) bez sumnje razvijati na način da sve više prate potrošača i njegove potrebe, kako bi ostvarili što bolju komunikaciju i razvili odnos s njime. Potrošač je danas moćniji nego ikad upravo zbog velikog izbora komunikacijskih kanala među kojima može birati i na kojima može preuzeti ulogu kritičara ili zagovornika pojedinog proizvoda, pa će uspješnost marketinške komunikacije sve više ovisiti o izboru komunikacijskih kanala i medija kojima nakladnik komunicira s čitateljima.

\section{LITERATURA}

Adams, D. The History of social media. // Instant Shift (2011). [citirano: 2017-03-16]. Dostupno na: http://www.instantshift.com/2011/10/20/the-history-of-social-media/.

Anubhav Mishra, S. M. S. eWOM: extant research review and future research avenues. // The Journal for Decision Makers 41, 3(2016), 222-233. DOI: https://doi. org/10.1177/0256090916650952.

Barreda, A.; A. Bilgihan; Y. Kageyama. The role of trust in creating positive word of mouth and behavioral intentions: the case of online social networks. // Journal of 
Relationship Marketing 14, 1(2015), 16-36. DOI: https://doi.org/10.1080/1533266 7.2015.1006002.

Birkner, C. Mom's the word. // Marketing News 45, 6(2011), 8. [citirano: 2017-03-12]. Dostupno na: http://connection.ebscohost.com/c/articles/60497347/moms-word.

Blackshaw, P.; M. Nazzaro. Consumer-generated media (CGM) 101: Word-of-mouth in the age of the web-fortified consumer. // Nielsen BuzzMetrics (2004). [citirano: 2017-03-12]. Dostupno na: http://www.nielsenonline.com/downloads/us/buzz/ nbzm_wp_CGM101.pdf.

Blažević, L. Moć marketinga u knjižnom nakladništvu. Zagreb: Naklada Ljevak, 2016.

Byle, A. Building buzz with social media. // Publishers Weekly, 259, 7(2012). [citirano: 2018-02-22]. Dostupno na: https://www.publishersweekly.com/pw/by-topic/industry-news/religion/article/50571-building-buzz-with-social-media.html.

Cordon-Garcia, J. A.; J. Alonso-Arevalo; R. Gomez-Diaz; D. Linder. Social reading: platforms, applications, clouds and tags. Oxford: Chandos Publishing, 2013.

Davis, M.; M. Walter. Next-wave publishing technology. Part 2: Revolutions in process. // Seybold Publications 3, 20(2010), 3-21.

Dimzov, S. Uloga sveučilišne knjižnice u digitalnom okruženju s obzirom na infromacijsko ponašanje studenata humanističkih znanosti: doktorska disertacija. Zadar: Odjel za informacijske znanosti Sveučilišta, 2016. [citirano: 2019-01-12]. Dostupno na: https://dr.nsk.hr/islandora/object/unizd:2038/preview.

Ferenčić, M. Marketinška komunikacija u digitalnom svijetu. // Praktični menadžment 3, 5(2012), 42-46.

Haramija, P. Marketing usmenom predajom: fenomen i mogućnosti. // Bogoslovska smotra 77, 4(2007), 881-900.

Hennig-Thurau, T.; K. P. Gwinner; G. Walsh; D. D. Gremler. Electronic word-of-mouth via consumer-opinion platforms: what motivates consumers to articulate on the Internet. // Journal of Interactive Marketing 18, 1(2004), 38-42. DOI: https://doi. org/10.1002/dir.10073.

Hilts, P., Direct marketing guru: publishers must use web to find new markets. // Publishers Weekly 246, 48(1999). [citirano: 2017-03-12]. Dostupno na: https://www.publishersweekly.com/pw/print/19991129/36868-direct-marketing-guru-publishersmust-use-web-to-find-new-markets.html.

IAB Croatia. Mediascope. // Iab Croatia, 2015. [2017-03-10]. Dostupno na: http://www. iab-croatia.com/mediascope/.

Jelić, N. Društveni mediji kao alat destinacijskog marketinga i njihova primjena od srane hrvatskih turističkih organizacija: diplomski rad. Zagreb: Ekonomski fakultet, 2015.

Jurić, M. Čitanje u tiskanom i digitalnom okruženju: doktorska disertacija. Zadar: Odjel za informacijske znanosti Sveučilišta, 2017. [citirano: 2019-01-12]. Dostupno na: 
https://bib.irb.hr/datoteka/907122.Juric_Mate_UNIZD_2017_Disertacija-Citanje-u-tiskanom-i-digitalnom-okruzenju.pdf.

Kaplan, A. M.; M. Haenlein. Users of the world, unite! The challenges and opportunities of social media. // Business Horizons 53, 1(2010), str. 59-68. DOI: https://doi. org/10.1016/j.bushor.2009.09.003.

Kesić, T. Integrirana marketinška komunikacija: oglašavanje, unapređenje prodaje, Internet, odnosi s javnošću, publicitet, osobna prodaja. Zagreb: Opinio, 2003.

Kietzmann, J.H.; K. Hermkens; I. P. McCarthy; B. S. Silvestre. Social media? Get serious! Understanding the functional building blocks of social media. // Business Horizons 54, 1(2011), 241-251. DOI: https://doi.org/10.1016/j.bushor.2011.01.005.

Kotler, P.; K. L. Keller. Marketing management. 15th Kindle ed. Harlow: Pearson Education Limited, 2016.

Kraus, T. Istraživanje tržišta knjiga u Hrvatskoj. Zagreb: GFK Hrvatska, 2018. [citirano: 2019-01-16] Dostupno na: https://issuu.com/modernavremena/docs/prezentacija_no_knjige_23.04.2018.

Lichtenberg, J. Thinking outside the book. // Publishers Weekly 246, 41(2000), [citirano: 2017-02-15]. Dostupno na: https://www.publishersweekly.com/pw/print/20001009/23303-my-say-thinking-outside-the-book.html.

Ljevak, P. Poslovne strategije nakladnika i korisnici digitalnih društvenih mreža: doktorska disertacija. Zadar: Odjel za informacijske znanosti Sveučilišta, 2017. [citirano: 2018-05-20]. Dostupno na: https://repozitorij.unizd.hr/islandora/object/unizd:1080/ preview.

Meuter, M.; D. Brown McCabe; J. Curran. Electronic word-of-mouth versus interpersonal word-of-mouth: are all forms of word-of-mouth equally influential? // Services Marketing Quarterly 34, 3(2013), 240-256. DOI: https://doi.org/10.1080/15332969 .2013.798201.

Moniz, K. Social media overview. // Tufts University, 2014. [citirano: 2017-03-17] Dostupno na: http://communications.tufts.edu/marketing-and-branding/social-media-overview/.

Mučalo M.; S. Šop. Nova publika novih medija. // Informatologija 41, 1(2008), str. 51-55.

Nakladništvo. // Hrvatska enciklopedija. Mrežno izd. Zagreb: Leksikografski zavod Miroslav Krleža, 2018. [citirano: 2019-01-15]. Dostupno na: http://www.enciklopedija. $\mathrm{hr} /$ natuknica.aspx?id=42840.

O’Reilly, K.; A. MacMillan; A. G. Mumuni; K. M. Lancendorfer. Extending our understanding of ewom impact: the role of source credibility and message relevance. // Journal of Internet Commerce 15, 2(2016), 77-96. DOI: $\underline{\text { http://dx.doi.org/10.1080/1 }}$ 5332861.2016.1143215. 
Pehar, F. Nakladništvo u mreži društvenih medija: novi publikacijski i komunikacijski pristup. // Ppt prezentacija: Sveučilište u Zadru. [citirano: 2018-03-10]. Dostupno na: http://ozk.unizd.hr/wp-content/uploads/2012/05/drustveni_mediji_u_nakladnistvu_dist.pdf.

Radalj, M. Knjiga i nakladništvo u odnosima s javnošću. Zagreb: Hrvatska sveučilišna naklada, 2016.

Sedo, D. R. Reading Communities from Salons to Cyberspace, Basingstoke: Palgrave Macmillan, 2011.

Stanojević, M. Marketing na društvenim mrežama. // Medianali 5, 10(2011), 165-179.

Tan, T. Children's books in China 2017: Social media marketing takes center stage. // Publishers Weekly, 264, 12(2017). [citirano: 2018-02-20]. Dostupno na: https:// www.publishersweekly.com/pw/by-topic/international/international-book-news/ article/73096-children-s-books-in-china-2017-social-media-marketing-takes-center-stage.html.

Thelwall, M.; K. Kousha. Goodreads: a social network site for book readers. // Journal of the Association for Information Science and Technology 68, 4(2017), 972-983. DOI: https://doi.org/10.1002/asi.23733.

Thompson, J. B. Books in digital age, Cambridge: Polity Press, 2005.

Thompson, J. B. Merchants of culture: the publishing business in the twenty-first century. Cambridge: Polity Press, 2010.

Tomašević, N. Istraživanje stajališta o čitanju i njihov utjecaj na nakladništvo: (ocjena zainteresiranosti za književne vrste). // Libellarium 1, 2(2008), 221-241.

Tomašević, N. Kreativna industrija i nakladništvo. Zagreb: Naklada Ljevak, 2016.

Živković, D. Elektronička knjiga. Zagreb: Multigraf, 2011. 